\title{
STRUCTURAL TRANSFORMATION, DEEP DOWNTURNS, AND GOVERNMENT POLICY
}

Joseph E. Stiglitz

Working Paper 23794

http://www.nber.org/papers/w23794

\author{
NATIONAL BUREAU OF ECONOMIC RESEARCH \\ 1050 Massachusetts Avenue \\ Cambridge, MA 02138 \\ September 2017
}

The views expressed herein are those of the author and do not necessarily reflect the views of the National Bureau of Economic Research.

NBER working papers are circulated for discussion and comment purposes. They have not been peer-reviewed or been subject to the review by the NBER Board of Directors that accompanies official NBER publications.

(C) 2017 by Joseph E. Stiglitz. All rights reserved. Short sections of text, not to exceed two paragraphs, may be quoted without explicit permission provided that full credit, including () notice, is given to the source. 
Structural Transformation, Deep Downturns, and Government Policy

Joseph E. Stiglitz

NBER Working Paper No. 23794

September 2017

JEL No. G01,L52,N12,O14,O25

\section{$\underline{\text { ABSTRACT }}$}

Most recessions are a result of some shock to the economic system, typically amplified by financial accelerators, and leading to large balance sheet effects of households and firms, which result in the effects persisting. But, over time, the balance sheets get restored. Even banks recover.

But episodically, the "shock" is deeper. It is structural. Among advanced countries, the movement from agricultural to manufacturing in the last century, and the more recent movement from manufacturing to the service sector reflect such a large economic transformation. The associated downturns are longer lasting. The usual responses, in particular, monetary policy, are only of limited efficacy. Policies have to be designed to facilitate such transformations: markets on their own typically do not do well.

This paper explains why such transformations are associated with persistently high unemployment, and describes the effects of particular government policies. It looks at the lessons of the Great Depression both for the advanced countries and the developing countries as they go through their structural transformations.

Joseph E. Stiglitz

Uris Hall, Columbia University

3022 Broadway, Room 212

New York, NY 10027

and NBER

jes322@columbia.edu 
Structural Transformation, Deep Downturns, and Government Policy

J. E. Stiglitz ${ }^{1}$

\begin{abstract}
Most recessions are a result of some shock to the economic system, typically amplified by financial accelerators, and leading to large balance sheet effects of households and firms, which result in the effects persisting. But, over time, the balance sheets get restored. Even banks recover.

But episodically, the "shock" is deeper. It is structural. Among advanced countries, the movement from agricultural to manufacturing in the last century, and the more recent movement from manufacturing to the service sector reflect such a large economic transformation. The associated downturns are longer lasting. The usual responses, in particular, monetary policy, are only of limited efficacy. Policies have to be designed to facilitate such transformations: markets on their own typically do not do well.

This paper explains why such transformations are associated with persistently high unemployment, and describes the effects of particular government policies. It looks at the lessons of the Great Depression both for the advanced countries and the developing countries as they go through their structural transformations.
\end{abstract}

\footnotetext{
${ }^{1}$ University Professor, Columbia University. Paper prepared for the Oxford Handbook of Structural Transformation, edited by Celestin Monga and Justin Yifu Lin. This paper is part of a larger research project with Bruce Greenwald. I wish to acknowledge the financial support of INET, research assistance of Matthieu Teachout and editorial assistance of Debarati Ghosh.
} 
Structural Transformation, Deep Downturns, and Government Policy

\author{
J. E. Stiglitz ${ }^{2}$
}

Economies are always changing, and one of the virtues of the market economy is its ability to adapt to these changes. Primitive agriculture economies face weather variability. Manufacturing economies are marked by new products. Rivals have to constantly adapt to the changing competitive landscape.

But beyond these changes, there are a few major structural changes, large changes that occur very infrequently. The movement from feudalism to the postfeudal era was such a change. The industrial revolution was another-but even after the onset of the industrial revolution, the economy remained largely agrarian. It was not until one hundred to one hundred and fifty years later that the structural change-the move from a rural agrarian economy to an urban manufacturing society occurred. That was a traumatic event. ${ }^{3}$

Markets don't handle such changes well, nor typically do the political processes governing markets. The purpose of this paper is (a) to explain why it is that markets on their own manage these transitions so poorly; (b) to show that when the structural transformation is not well managed, there may be a prolonged economic downturn (recessions and depressions), arguing that this is at least part of the explanation for the Great Depression and the Great Recession; (c) to analyze the effects of government actions that might help manage these structural transformations, and in particular, the role of industrial policy in facilitating these transitions; and (d) to set these industrial policies as a critical part of Keynesian counter-cyclical policies. We set much of our discussion in the context of the last major structural transformation confronting the advanced countries, the transition from being an agrarian economy to manufacturing, because we can see the principles better from the perspective of 80 years. But in

\footnotetext{
${ }^{2}$ University Professor, Columbia University. Paper prepared for the Oxford Handbook of Structural Transformation, edited by Celestin Monga and Justin Yifu Lin. This paper is part of a larger research project with Bruce Greenwald. I wish to acknowledge the financial support of INET, research assistance of Matthieu Teachout and editorial assistance of Debarati Ghosh.

${ }^{3}$ Described so forcefully by K. Polanyi, The Great Transformation, 1944, Farrar \& Rinehart.
} 
the last two sections of this paper, we discuss their implications for the 2008 recession and the broader management of cyclical fluctuations.

I. The failure of markets and politics to manage structural transformations

The reason for the failure of markets and politics to manage structural transformations is simple. The economic and political structures are designed for stability, including the maintenance of existing power relationships. The system is good at handling small shocks, but does not adapt well when managing big changes.

In the economic sphere, big changes lead to large (and typically unanticipated) changes in asset values. In the transition to manufacturing, as farmers migrated out of the rural sector, the assets owned by farmers (in particular, their homes) decreased in value. Their human capital was even more affected: farmers were well attuned to the nuances of weather, disease, etc. in their locale as it related to the production of the particular crops in which they specialized, but those skills were largely unrelated to the skills required for manufacturing.

Manufacturing occurs largely in urban centers (and for good reasons). The move from agriculture to manufacturing thus also required a massive change in the structure of housing.

Typically in a decentralized market economy, the individual is responsible for obtaining the human capital that he requires to be productive, beyond his basic education. Individuals are responsible too for relocation costs, including those associated with the purchase of a new home. ${ }^{4}$ In short, moving from the old sectors to the new sectors is difficult and requires resources. Structural transformation requires up front capital expenditures. Large fractions of individuals that should be making the transition do not have the resources to finance this transformation; and given the imperfections of capital marketswhich can be explained in terms of imperfections and asymmetries of

\footnotetext{
${ }^{4}$ There are good reasons for owner-occupancy; nonetheless, some market economies rely on rental housing, so that the provision of housing relies on specialized private enterprises. Here, the problem is that the net worth of these enterprises may suffer significant adverse effects in the process of structural transformation, and thus may not be able to provide the new housing required in the urban area. In this case, however, it is more likely that new enterprises will be created to provide housing for new migrants to the urban sector.
} 
information - they cannot obtain finance. Indeed, the structural transformation itself makes it even more difficult to obtain the finance. Banks that have invested substantial amounts in the rural sector (in the "old" sector) - that is, have lent substantial amounts to that sector-also experience significant losses. The fact that the value of housing in the rural sector has diminished implies that a fraction-perhaps a large fraction-of the loans will go into default. So too for loans made to finance other investments in the rural (old) sector. Thus, the net worth of banks will experience a negative shock. And this will reduce their ability and willingness to lend. ${ }^{5}$

Moreover, these local institutions have the detailed information that allows them to judge the creditworthiness of the borrower. But the structural transformation has attenuated even the value of that information, since knowing an individual's competence in the rural sector might provide only limited information about his performance in the urban.

Moreover, moving is risky: there are clear upfront costs, with large uncertainties about the returns. Will the individual find a good job, an adequate home, a community in which the family thrives? There are no markets to which individuals can turn to obtain insurance against these risks.

The result is that large changes in technology (and preferences) do not quickly get translated into the kinds of changes in the overall economy that one would have expected, if one analyzed the equilibrium that might have occurred using a model with costless mobility of resources. ${ }^{6}$ We will explain shortly how government intervention can facilitate the transition.

But here, too, we encounter difficulties. Political institutions tend to reflect existing power structures. And these existing power structures derive their power, at least to some extent, from their existing economic power, and the structural transformations under discussion undermine those power relations. Thus, rather than facilitating the transition, too often government lends its weight in the other direction, trying to preserve the status quo and the power structures associated with it. Nowhere is that more evident in the example which is the

\footnotetext{
${ }^{5}$ See B. Greenwald and J. E. Stiglitz, Towards a New Paradigm in Monetary Economics, 2003, Cambridge University Press.

${ }^{6}$ There are, in addition, large social costs. Individuals have built up networks of relationships which are not only a direct source of "utility" but also provide strong systems of social support.
} 
focus of the discussion of this paper, the movement from agrarian economies to manufacturing. The political institutions created in the nineteenth century gave undue weight to the rural agrarian communities, and the mindset of these communities may be at odds with that of dominant urban communities. While this disparity between politics and the underlying economic realities is stark, the disparity is even greater when it comes to the movement now underway into the postindustrial societies, to the service and knowledge based economies of the $21^{\text {st }}$ centuries. $^{7}$

\section{Interpretation of the Great Depression}

The Great Depression provides a good illustration of the principles just discussed, and the consequences of the impediments to an easy transition. The underlying "shock" to the economy leading to the downturn was an increase in agricultural productivity. ${ }^{8}$ In the absence of frictions, this would have moved the utilities possibilities curve outward, i.e. assuming that lump sum redistributions were possible, everyone could have been made better off. (Without government

\footnotetext{
${ }^{7}$ While a political system disproportionately representing the agrarian mindset only put minor roadblocks in the creation of the manufacturing economy, the impediments put in place by a political system with disproportionate weight given to the rural and dying manufacturing regions of a country for the efficient development of the postindustrial economies may be far greater. An interesting aspect of manufacturing in the US today is that much of it has moved out of the urban areas to more rural locations. Low wages, low costs of land, and good transportation system reversed the earlier advantages of urban locations.

${ }^{8}$ We do not present the evidence for this claim here. Note though that there was a drop in income of farmers of some 50 percent to 75 percent, and that the rural sector represented some 70 percent of the economy at the time. With reasonable multipliers, it is easy to see how this could translate into a macroeconomic downturn of the magnitude observed.

There is a long-standing debate about the relative importance of different factors in contributing to the Great Depression, with some economists (e.g. B. Eichengreen, Golden Fetters: The Gold Standard and the Great Depression, 1919-1939, Oxford University Press, 1992) emphasizing the role of the gold standard and others (e.g. M. Friedman and A. J. Schwartz, A Monetary History of the United States, 1867- 1960, Princeton University Press, 1963) that of monetary policy. Both of these clearly played a role, especially in the propagation and persistence of the downturn. We emphasize here, however, the role of the "productivity shock" in agriculture as the source of the perturbation to the economy. The gold standard did introduce rigidities, making adjustment to the shock more difficult. It is often noted that countries that went off the gold standard performed better. But this says nothing about what would have happened if all had gone off the gold standard. Countries going off the gold standard early clearly had a competitive advantage over those that waited. A discussion of the role of monetary policy as a cause of the crisis would take us beyond this short paper. Here, we simply note that the financial crisis occurred years after the onset of the Depression. Any deep and prolonged downturn will give rise to a financial crisis.
} 
intervention, the effects are ambiguous, since the competitive equilibrium could entail some group being worse off. This is the case with Hicksian labor-saving technological changes.) In the new equilibrium, workers would have migrated from the rural sector to the urban sector. Fewer workers are needed to produce the food required. This is because the income elasticity and price elasticity of food is low. The technological change leads to lower prices of agricultural goods, and this results in slightly higher demands-an increase in demand that is smaller than the increase in productivity. Hence, incomes in the rural sector decline and workers migrate from the rural to the urban sector.

With the real frictions described in the previous section, this may not be the case. Assume for the moment that mobility is zero. Then those in agriculture will see their incomes go down, and as a result they will work harder (assuming income effects offset substitution effects) and this will lead to further decreases in agricultural prices and incomes. (Each farmer believes that by working harder, his income will increase, but, because of the inelasticity of demand, when output increases, incomes actually fall.) Those in the urban sector are better off-at first. But with farmers demanding fewer tractors and cars and other manufactured goods, the demand for urban goods decreases. Assume, again for simplicity, that wages are fixed-say at the efficiency wage. Then employment in the urban sector falls, leading to a decrease in demand for food, further depressing the price of food. The equilibrium that emerges entails lower food prices and lower urban employment-in both sectors, workers are worse off. ${ }^{9}$ What should have been an innovation could have made everyone better off-if the structural transformation could have efficiently been carried out-leads to immiseration, with welfare in both the rural and urban sectors decreased. ${ }^{10}$

\footnotetext{
${ }^{9}$ The lower wages increase the income of the owners of capital. So long as the marginal propensity to consume of these capitalists is lower than that of workers, the results described here hold. The adverse welfare effects hold so long as the marginal social utility of a dollar to the (higher income) capitalists is lower than that to workers. Of course, workers who do retain jobs at the efficiency wage are unaffected. Note that the efficiency wage (in terms of the prices of manufactured goods) may be lowered, because the price of food is lowered.

${ }^{10}$ Formal models showing what has been discussed in the previous section are provided in D. Delli Gati, M. Gallegati, B. Greenwald, A. Russo and J.E. Stiglitz, "Mobility constraints, productivity trends and extended crisis", Journal of Economic Behavior and Organization, Vol 83 (3), 2012 and D. Delli Gatti, M. Gallegati, B. Greenwald, A. Russo and J.E. Stiglitz, "Sectoral imbalances and long-run crises", in The Global Macro Economy and Finance (pp. 61-97), edited by J. Fitoussi, R. Gordon and J.E. Stiglitz, Palgrave Macmillan UK.
} 
It is interesting that President Roosevelt's first response to the Great Depression (embodied in the Agricultural Adjustment Act of 1933) was to restrict agricultural production. This would have increased incomes in both the rural and urban sectors. (Rural welfare would have been increased both because of the higher prices they receive for the goods they sell. ${ }^{11}$ ) It was struck down by the Supreme Court, and widely criticized by economists, as an intervention in the workings of the market economy. But it was, in fact, a clever application of the principle of the second best. Given the market distortion (the inability of labor to move costlessly across sectors, and the inability to engage in lump sum redistributions) such interventions may in fact have been desirable.

In the end, it was World War II that brought the US economy out of the Great Depression. The demand for munitions and armaments and troops required moving people out of the rural sector, and training individuals for a manufacturing society helped in the transition. After the war, the GI bill, which provided a university education to all of those who had fought in the war (which was almost all men, and many women) provided the human capital needed for the transformation from an agrarian economy to a manufacturing economy. The forced savings during the war and deferred consumption helped provide the basis of strong aggregate demand, substituting for government military expenditures which diminished rapidly after the war, thus averting the widely expected postwar recession.

In short, war expenditures were more than a Keynesian stimulus; they constituted (unknowingly) an industrial policy, critical in engineering a structural transformation.

\section{Interpretation of the 2008 crisis}

The 2008 crisis is often thought of as a financial crisis - and clearly, as part of the crisis, many financial institutions were close to collapsing. But to understand the crisis itself and what could have been done to help the economy emerge from it, we must dig deeper.

\footnotetext{
${ }^{11}$ As producers (seller of agricultural goods), we can express their welfare through an indirect utility function depending just on the price of agricultural goods relative to urban goods.
} 
By analogy to the Great Depression, one can think of globalization and the increases in productivity in manufacturing as the underlying drivers of the Great Recession. The growth in productivity in manufacturing has exceeded the growth in demand for manufactured goods, and that means globally, there will be a decrease in manufacturing employment; and globalization means that the advanced countries will be seizing a diminishing share of this diminishing amount. But that in turn means these workers have to find employment elsewhere. One way of thinking of the real estate bubble in the US was that it was one way that the US temporally solved the problem. It provided jobs for the men who had lost jobs in manufacturing.

So too, the low interest rates of the Federal Reserve which fed the housing bubble were a reflection of the weak aggregate demand resulting from the underlying weakness in manufacturing. There were, of course, other ways by which the economy/society could have responded. There could have been an increase in fiscal expenditures. So too, monetary policy might not have led to a real estate bubble under alternative regulatory frameworks.

Of course, the collapse of the financial sector amplified the downturn.

Given that the obvious symptom of the crisis was the collapse of a major bank, Lehman Brothers, and the real threat of the collapse of the entire financial sector, in the aftermath, it was natural to refer to the crisis as a financial crisis. That led to a focus on the financial sector, including its recapitalization. But years later, when the banks were largely recapitalized, the downturn continued, suggesting at least that the downturn was not just a financial crisis.

So too, some have said it was a "balance sheet recession." Essentially all major downturns are balance sheet downturns, i.e. the downturn leads to a weakening of the balance sheets of firms as well as banks, and this leads to a contraction both of production (in effect, a shift of the aggregate supply curve to the left) and demand-a shift in the demand curve for investment. There is nothing distinctive in this matter for the 2008 crisis. ${ }^{12}$ And again, by a few years after 2008, balance

\footnotetext{
${ }^{12}$ For an analysis of balance sheet recessions, see B. Greenwald and J. E. Stiglitz, "New and Old Keynesians", Journal of Economic Perspectives, 7(1), Winter 1993, p23-44; B. Greenwald and J. E. Stiglitz, "Financial Market Imperfections and Business Cycles," Quarterly Journal of Economics, 108(1), February 1993, pp. 77-114; B.
} 
sheets were largely restored: large corporations were sitting on a couple trillion dollars of cash. It was not balance sheets that were constraining investment, but aggregate demand. The question was, what was constraining aggregate demand?

Our analysis suggests it was the failure to advance on the necessary structural transformation, transforming the US from a manufacturing economy to a service sector economy. Just as farmers were "trapped" in the agricultural sector, unable to move to the manufacturing sector, so too now manufacturing workers are trapped, lacking the skills that would enable them to be productive in the expanding sectors of the economy and unwilling and unable to make the investments that would give them the skills and move themselves to the locations where the jobs were being created. ${ }^{13}$

Again, Keynesian policies could have filled in the void in aggregate demand, but in fact, the growth of public sector employment fell short of what would have been expected on the basis of the growth of the working age population. As in World War II, structural Keynesian policies might have succeeded in facilitating the structural transformation, with industrial policies supporting the new sectors, and retraining policies (active labor market policies) helping move people form the old sectors to the new.

The changing structure of the economy towards services itself has important implications: many of the sectors into which the economy was shifting were service sectors in which government traditionally has played a pivotal role, like education, health and care for the aged. Without government support, these sectors were constrained, and so as the manufacturing sector declined, the new sectors where workers might naturally have found employment didn't grow.

IV. Remarks on industrial policies as cyclical policies ${ }^{14}$

Greenwald and J.E Stiglitz, Towards a New Paradigm of Monetary Economics, 2003, op. cit.; and R. Koo, Balance sheet recession: Japan's struggle with uncharted economics and its global implications, 2003, John Wiley \& Sons.

${ }^{13}$ There are a host of other impediments to mobility, including the reluctance to leave one's extended family and support systems. The absence of a good rental market for housing impedes mobility, as does the lack of affordable day care, in those instances where members of the extended family provide such services.

${ }^{14}$ Industrial policies include any policies which help direct resources to or from a sector or encourage the adoption of a particular technology within a sector. They are not limited to the promotion of "industry," as that term is usually understood. As I have noted elsewhere, all countries have industrial policies, hidden in the tax code or various aspects of the legal code. Markets don't exist in a vacuum; they have to be structured, and inevitably, how they are structured affects resource allocations. Of course, government interventions in resource allocations 
The two previous sections have emphasized the market failures that emerge in a structural transformation. There is a natural role for government in correcting these market failures. In particular, Keynesian policies can stimulate the economy. In the case of the transformation from agriculture to industry, they increased incomes in both the agriculture and urban sectors. The increased incomes by themselves would have facilitated the movement from the rural to the urban sector, thus partially addressing one of the key market failures. But the expenditures during and after World War II were even more effective in enabling the transformation; they were unintentionally industrial policies, helping people move and giving them the training and education needed to equip them to be productive in the expanding sectors of the economy. There is a general principle here: when the underlying problem facing an economy is the necessity of a major economic transformation, a key component of Keynesian cyclical policies are industrial policies to facilitate that transformation.

Managing such policies is, however, not always easy.

When a sector is facing competition from those outside the country, those in the sector will often claim either that there is unfair competition from abroad and/or the problems are only temporary, and a little help will enable the industry to recover and thrive. (It is more efficient to provide short term support to the industry than to relocate the workers and see a long-term loss in human and organization capital, which would result from the closure of enterprises.)

Both workers and firms have a self-interest in taking such a stance. Even a successful relocation of workers may be associated with significant lowering of

\footnotetext{
become more compelling when there is a market failure-as here, a failure in the free mobility of labor. See D. Rodrik, "Industrial Policy for the twenty-first century", CEPR Discussion Paper No. 4767, 2004; B. Greenwald and J.E. Stiglitz, "Industrial Policies, the Creation of a Learning Society, and Economic Development" in The Industrial Policy Revolution I: The Role of Government Beyond Ideology, J. E. Stiglitz and J. Yifu Lin (eds.), Houndmills, UK and New York: Palgrave Macmillan, pp. 43-71; and J. E. Stiglitz, "Industrial Policy, Learning and Development", in The Practice of Industrial Policy: Government-Business Coordination in Africa and East Asia, John Page and Finn Tarp (eds.), Oxford: Oxford University Press, 2017, pp. 23-39.
} 
wages. Older workers trained for one sector may, even with retraining, be less productive in the new sector. There are several issues that have to be addressed.

First, is the problem temporary? Often, it is not. Comparative advantages do change. The US almost surely does not have a comparative advantage in the production of cars. Germany, Japan, Korea, and China seem to have comparative advantages in different parts of the product spectrum, with Germany having a comparative advantage in high tech cars, and Korea and Japan in more mass produced cars. The US comparative advantage in large gas guzzlers is not the basis of a successful $21^{\text {st }}$ century automobile industry. The US car companies have returned to profitability, but only by substantially lowering wages of their workers.

Both firms and workers in the declining industry have an incentive to try to claim that the industry is just facing temporary difficulties, and a little help-if not outright subsidies, then a little protection-would do the trick. Ascertaining whether the industry is facing temporary difficulties or has lost its long term comparative advantage is not easy.

Second, domestic firms are always going to claim that competition from outside-when it is successful-is unfair. They have to believe that they are more productive than firms elsewhere, so that if competition were fair, they would prevail. But the reality is often otherwise. It is not "unfair" for a country to be poor and have low wages; it is unfortunate. The principle of comparative advantage says that even low wage countries have comparative advantages and disadvantages. Again, of course, every firm complains about hidden subsidies. Those abroad complain about US bailouts which are given to its auto companies. Indeed any firm that borrows from an American bank is a beneficiary of the hundreds of billions of dollars that went to the financial sector in the bailout. Those outside the US claim that that gives American firms an unfair advantage. US monetary policy which keeps interest rates at near zero too is seen as giving American firms an unfair source of cheap capital.

But there are cyclical fluctuations, and these fluctuations affect some industries more than others - the cyclically sensitive sectors. Minimizing the deadweight 
loss associated with cyclical fluctuations entails doing what can be done to stabilize the economy through monetary and fiscal policy. One of the market failures which we have noted is the absence of state contingent insurance, and government provision of such insurance - that is, insurance which paid off in the event of a cyclical downturn-increases economic efficiency, and likely would also increase stability.

Industrial policies, however, can be an important complement to these policies; and take on even greater importance as second best measures when the government fails to implement them fully effectively. Industrial policies can simultaneously help the industry manage the downturn without excessive adverse effects to firms' balance sheets (which would impede long run competitivity) and assist in the restructuring itself. Because of capital market imperfections, an economic downturn, especially in a capital intensive industry with economies of scale, can lead to large (cash flow) losses, deteriorating balance sheets and inhibiting the ability to modernize and compete.

Roosevelt's Agriculture Adjustment Act, as we noted, is an example of such a policy. ${ }^{15}$ So too are state contingent tariffs, which increase tariffs or reduce quotas in a recession, so that producer prices are increased, reducing the losses confronting cyclically sensitive industries.

Persistent unemployment is, in a sense, a symptom that the market economy is not working well. We have also described how government interventions can, in such circumstances, provided symptomatic relief. While there may be policies that go more directly at the root of the problem, it is better to intervene with second or third best measures than to let the economy suffer from prolonged unemployment.

\section{Concluding Remarks}

\footnotetext{
${ }^{15}$ Conventional literature has emphasized the market distortions associated with these policies. Here, we are emphasizing the second and third best nature of these policies. Obviously, it would be preferable to eliminate the cyclical fluctuations, or to manage the risk with state contingent insurance. It would be preferable too to live in a world without capital constraints-but imperfections of information mean that these imperfections will always be there.
} 
Markets typically don't work as well as the textbook models of perfect markets would suggest. At times, these market failures become very significant, and government intervention is required. This paper has discussed one such instance-the structural transformation of an economy. We have explained why market failures are likely to be particularly significant when the economy is going through a major structural transformation, and described some of the market interventions that might address the market failures and facilitate the structure transformation. When structural transformations are not managed well, the result can be deep and prolonged downturns. In such situations, Keynesian industrial policies may simultaneously stimulate the economy, reduce unemployment, and facilitate the required transition. 